\title{
Formation of attribute collection of Callistephus chinensis (L.) Nees in Institute of gardening of NAAS
}

\author{
Shevel L. ${ }^{1}$, Trokhymchuk A. ${ }^{2}$ \\ Institute of gardening of NAAS, Sadova Str., 23, Kyiv, 03027, Ukraine; e-mail: ª.trokhymchuk@ukr.net
}

The purpose. To study and allocate grades of Callistephus chinensis with high economic valuable attributes and to generate attribute collection of the culture. Methods. Field (fixation of period of flowering, diameter of inflorescence, height of a plant, its stability against fusarial wilt, etc.); laboratoryfield (weigh of seeds by means of laboratory weights, determination of color of raceme according to RHSscale of colors); comparative; generalizations; statistical with application of dispersive analysis. Results. The economic assessment is made of genofund of Callistephus chinensis, and attribute collection is formed. Grades of selection of Institute of gardening of NAAS with high economic valuable attributes are allocated and registered in 2016 in National center of genetic resources of plants of Ukraine (NCGRPU) (Kharkiv): Shokoladka, Oksamyt, Rubinovi zirky (standard), Kazka in collection by the basic attribute «red color of raceme». Conclusions. Productive adding into genetic fund of plants of IG of NAAS of Callistephus chinensis made it possible to determine its varieties which are the sources of decorative effect, and to register the collection created by the basic attribute - «red color». On the complex of economic valuable attributes some varieties of selection of the institute were allocated: Shokoladka, Barkhat, Rubinovi zirky (standard), Kazka. Their plants were characterized by high decorative effect ( 9 points), diameter of inflorescence $(10-13 \mathrm{~cm}$ ), parameters of weight of 1000 pieces of seeds (up to 3,3 $\mathrm{g} / \mathrm{bush}$ ) and stability against disease-producing factor Fusarium oxysporum (9 points). The last is one of the major factors causing decrease of productivity of seeds of Callistephus chinensis in forest-steppe zone of Ukraine and in other regions. Assessment of attribute collection showed that almost $80 \%$ of varieties practically were not amazed with this illness. Insignificant contamination by that diseaseproducing factor (1 $-1,5$ points) was revealed at plants of variety Pavlyny and variety Carmen.

Key words: Callistephus chinensis, variety, attribute, collection, resistance.

https://doi.org/10.31073/agrovisnyk201809-04

Flower-decorative crop production is, at the moment, a sub-sector of the agrarian sector whose task is to replant and cultivate seeds and planting material of flowering plants for the purpose of their further use in the creation of plantations of various functional purposes. Therefore, the search for a diversity of plants that would meet the needs of producers and other segments of the population is an issue today.

Kalistefus Chinese hopes for cultures, both popular in our country, and throughout the world. Its distribution range covers China, Japan, the Korean Peninsula, the extreme south-west of the Far East [1]. Cultivated this flower from 1728. For three centuries, varieties with different habitats of plants have been created: size, shape, color of inflorescences; Unrivaled resistance to environmental factors and harmful organisms.

The need of the population in flowers was and remains high, therefore, demand for them does not decrease, but, on the contrary, increases. Recently, the foreign expansion of decorative and flower crops on the domestic market has greatly expanded. But only at the expense of increasing the existing areas of this problem can not be solved. The demands of the time put new tasks to the breeders, which in turn give rise to many questions, both scientific and practical.

The purpose of our research was to comprehensively study the Chinese Kalistefus gene pool and to create a collection based on the general unifying feature of the "red inflorescence" varieties of plants with different shades.

Methods and conditions. The research was conducted during 2010-2016 in the research field of the Institute of Horticulture (IS) of NAAS, located in the western forest-steppe of Ukraine. The region is 
characterized by moderately continental climate. The average annual temperature is $7.3^{\circ} \mathrm{C}$, the average of the hottest month (July) is $20.0^{\circ} \mathrm{C}$, and the coldest (January) is minus $5.8^{\circ} \mathrm{C}$. According to averaged data, in the last 15 years the maximum air temperature in the summer reaches $+39^{\circ}$, the minimum in winter is minus $36^{\circ} \mathrm{C}$. The transition of the average daily temperature through the $0^{\circ} \mathrm{C}$ limit occurs after March 20, more than $+5^{\circ} \mathrm{C}$ in the first decade of April, above $+10^{\circ} \mathrm{C}$ in the first decade of May, below $5^{\circ} \mathrm{C}$ - in the fall is indicated in the third decade of October. During the research period, the smallest amount of precipitation $(282.2 \mathrm{~mm})$ was recorded in 2015, the largest $(659.4 \mathrm{~mm})$ in 2011 . The sum of active temperatures ( $10^{\circ} \mathrm{C}$ and above) ranged from 3063 (2011) to $3451^{\circ} \mathrm{C}$ (2012). Most of the winters were "soft", the minimum air temperature was minus 16,1-26,6 $0 \mathrm{C}$, in the most severe winter (2012) minus 28,40C. Weather conditions of the growing season 2010, 2011, 2013, 2015 were unstable (insufficient or uneven distribution of precipitation), in some years and periods they negatively influenced the terms and peculiarities of the passage of certain phenophases in plants and the terms of harvesting and quality of seeds.

The relief of the experimental area is even. The ground is dark gray, podzolized, medium argillaceous in carbonate forest, typical for the northern part of the forest-steppe of Ukraine. His analysis was carried out at the Laboratory of Agrochemistry IS NAN. The content of humus in the arable layer $(0-40 \mathrm{~cm})$ is $2.3 \%$, of lighthydrolyzed nitrogen (by Tyurin and Kononovoy) from 78.4 to $98.0 \mathrm{mg} / \mathrm{kg}$, mobile forms of phosphorus (according to Kersanov) 93.2-180, $9 \mathrm{mg} / \mathrm{kg}$, exchangeable potassium (according to Kersanov) $106.1-202.8 \mathrm{mg} / \mathrm{kg}$. The reaction of their soil solution of acid - $\mathrm{pH}$, respectively, 5,3-5,8 and $5,5-6,1)$ The ratio of physical sand to physical clay is 69 to $31 \%$.

Ground water is at a depth of $5-6 \mathrm{~m}$. In granulometric composition and nutrient content, the soil of the experimental area is quite suitable for growing the investigated plant.

The objects of the study were 23 varieties of Chinese Kalistefus from the collection of "red inflorescences" of various shades.

The laying and conducting of experiments, basic records and observations was carried out in accordance with the "Methods of carrying out the qualification examination of varieties of floral, decorative, essential oils, medicinal and forestry plants for suitability for distribution in Ukraine" [2] and "Methods of conducting the examination of the Chinese kalistefus varieties (Callistephus chinensis L.) Nees) on difference, homogeneity and stability "[3], and preparation of collections and samples for registration - in accordance with the requirements of NCGGRU.

\section{Research results.}

Kalistefus chinese is widely distributed in many countries, including Ukraine, among annual flower crops due to the versatility of its use $[4,5,6]$. The growing popularity of this plant is due to the large number of colors and forms of inflorescences, prolonged flowering, unpretentiousness to cultivation and many other factors.

In 2016 the NCGGR registered a featured collection of Callistephus chinensis (L.) Nees for 31 signs of "red inflorescence", including origin of the Ukrainian - 14 varieties, German - 4, French - 1, Russian - 2, westernEuropean - 2. The tables show the data on the breeds selection Institute of Horticulture (NAAS).

Studies of this collection in the samples of Chinese kalistefus - Lyudmila and Esperance have shown that they saw the early stages of flowering. Most of them $(60 \%)$ begin to flower from the first decade of August. The late flowering (the second - the third decade of this month) was recorded in varieties: Carmen, Kirchwell, Pavlina, Chocolate, Sonata, Eve. Very late (the third decade of August - the first of September), plants of Sedoyi Lady and Krasunya flower (Table 1).

As for the height of plants, they are the highest (more than $80 \mathrm{~cm}$ ) in Serce Franc, but in most of the varieties, namely: in 12 samples of the collection collection are considered high $(61-80 \mathrm{~cm})$. The height up to $60 \mathrm{~cm}$ (average) is noted in Bukett Crimson, Lyudmila, Malinovaya layer, Malinovsky blesk, Sonata, Oxamit and Eve. Low-growing $(24-40 \mathrm{~cm})$ plants include Zwerg Aster and Pommax.

Inflorescences of Kalistefus of Chinese can be very varied in shape, diameter and color. On the first sign, they are divided into completely flattening (Valderzee, Kometa, Margarita, Unikum), flattened-rounded (Ambria, Victoria, Princess, Straw Pen, Riviera), semispherical (Needle, Radiant, Artistic, Triuf, Pioneer- 
like), spherical or spherical (American bush, American Beauty, Bullet). The form is closely related to the inflorescence of the inflorescence: as a rule, it is more elevated, the more spherical its shape becomes inflorescence [7,8]. The research has shown that $60 \%$ of varieties form inflorescence spherical; in the Malinovaya layer and Prince Pleskata, Kirchwell, Zwerg Aster, Princess Red, Pommax - Rounded, Danny Mother, Sedoye Lady, Esperance, Velvet - Spherical.

An important feature that determines the level of decorative varieties is the fullness of inflorescences. In Kalistefus Chinese they are divided into simple, semi-simple, full, and very full. This feature is divided by the number of rows of cilantric flowers in the basket, and the degree of inflorescence of inflorescence from the conditions of cultivation and agrotechnics [9].

The study of the density of inflorescences showed that in $62 \%$ of the varieties it is complete (many rows), the plants Zwerg Aster, Malinovyy layer, Pommax and Princess are semi-full, and Kirchwell, Pavlina, Sedoye Dame, Oxamita, Krasuny and Sonata are very complete. In most of the varieties $(60 \%)$ the density of inflorescence is average, in Ruby's dense branches, in all other samples of the collection is not tight.

Table 1. The economic value of some varieties of kalistefus of Chinese breeding IH NAN (2010-2016).

** - In 2018 will be registered in the database of NCGGUU.

\begin{tabular}{|c|c|c|c|c|c|c|}
\hline \multirow{3}{*}{$\begin{array}{l}\text { No. National } \\
\text { Catalog }\end{array}$} & \multirow{3}{*}{ Cultivation } & \multirow[b]{2}{*}{$\begin{array}{c}\text { The time for } \\
\text { flowering }\end{array}$} & \multirow[b]{2}{*}{$\begin{array}{c}\text { Average } \\
\text { plant height, } \\
\mathrm{cm}\end{array}$} & \multicolumn{3}{|c|}{ Inflorescence } \\
\hline & & & & form & type & density \\
\hline & & 1 & 2 & 3 & 4 & 5 \\
\hline UT2300022 & Carmen & $\begin{array}{l}\text { II - III decade } \\
\text { of August }\end{array}$ & 70 & Spherical & Complete & Medium \\
\hline UT2300053 & Princess Red & $\begin{array}{l}\text { I-decade of } \\
\text { August }\end{array}$ & 70 & Округла & Complete & Not tight \\
\hline UT2300055 & Pavlina & $\begin{array}{l}\text { II - III decade } \\
\text { of August }\end{array}$ & 70 & Spherical & Very full & Medium \\
\hline UT2300066 & $\begin{array}{l}\text { Rubinovyye } \\
\text { Zvyozdy } \\
\text { (standard) }\end{array}$ & $\begin{array}{l}\text { I-decade of } \\
\text { August }\end{array}$ & 70 & Spherical & Complete & Dense \\
\hline UT2300070 & Sedaya Dame & $\begin{array}{l}\text { II Dec. } \\
\text { August } \\
\text { September }\end{array}$ & & Cutie & Very full & Not tight \\
\hline UT2300093 & Shocoladka & $\begin{array}{l}\text { I-decade of } \\
\text { August }\end{array}$ & 70 & Spherical & Complete & Medium \\
\hline UT2300102 & Oxamyt & $\begin{array}{l}\text { I-decade of } \\
\text { August }\end{array}$ & 58 & Cutie & Very full & Medium \\
\hline ** & Krasuny & $\begin{array}{l}\text { II Dec. } \\
\text { August - } \\
\text { September }\end{array}$ & 55 & Cutie & Very full & Dense \\
\hline ** & Kazka & $\begin{array}{l}\text { I-decade of } \\
\text { August }\end{array}$ & 70 & Cutie & Complete & Dense \\
\hline $\mathrm{HIP}_{05}$ & & & 9,5 & - & - & - \\
\hline
\end{tabular}

One of the conditions of the value of a variety of any flower culture is decorative. This indicator depends on the diameter, color and its color stability to burnout. The size of the inflorescences may be small (only $4 \mathrm{~cm}$ in diameter) (Amburia, Valderzee, Liliput, Triumph, Edelweiss) and very large (more than $12 \mathrm{~cm}$ in diameter) (Gol'tsy, Unikum, Art, etc.) [10, 11, 12] . The color varies from white to dark red, passing all the shades - from pink to dark violet. Less common yellow color of tribal flowers (Electra, Burma, Memory). 
However, in the registered collection, the main feature ("red inflorescence") in all varieties is red or red (according to RHS - color scale) (see Table 2). The color of inflorescence in plants of all sorts of the collection does not burn out, except for the variety Krasunya, in which this figure during the flowering period is not stable.

The method of researching the Kalistefus chinese varieties also involves studying the samples of this crop taking into account the following basic indicators of the quality of the seeds (including seed crops), such as seed form, its purity, humidity, germination energy, laboratory similarity and the mass of 1000 pieces. According to the data obtained, $50 \%$ of the varieties were seeded in narrow-celled form, and the rest was broad-celled. As to the mass, it is established that the larger and heavier the seeds, the more it contains nutrients and better developed embryos. Plants grown from such seeds are high-yielding [8]. In the majority of studied varieties of varieties has an average and a large mass of 1000 pieces of seed was (1.8- $2.8 \mathrm{~g})$. Very high (3.1-3.3 g) this indicator, and with it a large number of nutrients was noted in the seeds of varieties Shokoladka, Sedaya lady and Pavlina (Table 2). One of the main reasons for decreasing the yield of Callistephus chinensis (L.) Nees in the forest-steppe zone of Ukraine, as in other regions, is the degree of damage of plants by fusarium (Fusarium oxysporum) [9]. The evaluation of the collection collection has shown that almost $80 \%$ of varieties are practically not affected by this disease. Its negligible pathogen of defeat (8.6-8.8) was found in Pavlini plants, Carmen.

Table 2. The economic and valuable indicators of some varieties of kalistefus of Chinese Ukrainian selection (2010-2016). IH NAAN

\begin{tabular}{|c|c|c|c|c|c|}
\hline \multirow{3}{*}{ Cultivation } & \multicolumn{3}{|c|}{ Inflorescence } & \multirow[b]{2}{*}{ Seed form } & \multirow{2}{*}{$\begin{array}{c}\text { Weight } 1000 \text { pcs. } \\
\text { seed, } g\end{array}$} \\
\hline & $\begin{array}{c}\text { Diameter } \\
\mathrm{cm}\end{array}$ & color & $\begin{array}{l}\text { stability of color to } \\
\text { solar radiation }\end{array}$ & & \\
\hline & 1 & 2 & 3 & 4 & 5 \\
\hline Carmen & 11 & 182A (beetroot) & Does not burn out & Narrow-shaped & 2,2 \\
\hline Princess Red & 6 & $\begin{array}{l}45 Д \\
\text { (red) }\end{array}$ & Does not burn out & Narrow-shaped & 2,8 \\
\hline Pavlina & 11 & $\begin{array}{c}58 \mathrm{C} \\
\text { (light red) }\end{array}$ & Does not burn out & Narrow-shaped & 3,0 \\
\hline $\begin{array}{l}\text { Rubinovyye } \\
\text { Zvyozdy } \\
\text { (standard) }\end{array}$ & 11 & $\begin{array}{l}61 \mathrm{C} \\
\text { (ruby) }\end{array}$ & Does not burn out & Narrow-shaped & 1,8 \\
\hline Sedaya Dame & 11 & $\begin{array}{c}59 \mathrm{C} \\
\text { (dark red with a } \\
\text { white stripe) }\end{array}$ & Не вигорає & Wide-Cyclone & 3,1 \\
\hline Shocoladka & 11 & $\begin{array}{c}184 \mathrm{~A} \\
\text { (chocolate-red) }\end{array}$ & Does not burn out & Narrow-shaped & 3,3 \\
\hline Oxamyt & 11 & $\begin{array}{c}45 \mathrm{~A} \\
\text { (bright red) }\end{array}$ & Does not burn out & Narrow-shaped & 2,2 \\
\hline Krasuny & 13 & $\begin{array}{c}\text { 58B } \\
\text { (crimson-red) }\end{array}$ & burns out & Wide-Cyclone & 2,3 \\
\hline Kazka & 13 & $\begin{array}{c}46 \mathrm{~B} \\
\text { (bright red) }\end{array}$ & Does not burn out & Wide-Cyclone & 2,4 \\
\hline & 2,3 & - & - & - & 1,15 \\
\hline
\end{tabular}

\section{Conclusions}

Effective maintenance of the genetic fund of plants in the Institute of Nanavan Academy of Sciences allowed to determine the varieties of Kalistefus of China, which are sources of decorative, and allowed to register the created collection on the main feature - "red color". By the complex of economic values were 
selected breeds of the named institute: Chocolate, Velvet, Ruby's sewn (standard), Tale. Their plants are characterized by high decorative character (9 points), inflorescence diameter $(10-13 \mathrm{~cm})$, mass indexes 1000 pcs. seed (up to $3.3 \mathrm{~g} / \mathrm{bush}$ ) and resistance to the pathogen Fusarium oxysporum (9 points).

\section{Bibliography}

1. Metodyka provedennia ekspertyzy sortiv kalistefusu kytaiskoho (Callistephus chinensis (L.) Nees) na vidminnist, odnoridnist ta stabilnist. [Method of conducting examination of the Chinese kalistefus varieties (Callistephus chinensis (L.) Nees) for difference, homogeneity and stability]. Okhorona prav na sorty roslyn. Ofitsiinyi biul. Part 3. 2006. №3. P. 58-74. [in Ukrainian].

2. Metodyka provedennia kvalifikatsiinoi ekspertyzy sortiv kvitkovo-dekoratyvnykh, efirooliinykh, likarskykh ta lisovykh roslyn na prydatnist do poshyrennia $\vee$ Ukraini. [Method of carrying out the qualification examination of varieties of floral, decorative, eyeliner, medicinal and forest plants for suitability for distribution in Ukraine]. Kyiv: Naukova dumka. 2007. P. 134. [in Ukrainian].

3. Shevel L.O. (2000). Aistry z Kytaievo. [Astri from Kitaevo]. Kvity Ukrainy. №8. P. 5-7. [in Ukrainian].

4. Poletyko O.M. (1985). Dekorativnye travjanistye rastenija otkrytogo grunta. [Decorative grassy plants of open ground]. Kiev. 207 p. [in Russian].

5. Doorenbos J. (1959). Response of China Aster to daylenght and gibberellis acid. J. plant. Breeding. 1959. Vol. 8, No. 1. P. 235-242.

6. Wittmack L. (2003). Die Waldersee and Apollo-Aster. Gartenflora. Bd. 52. 225 p.

7. Schmidt E. (2003). Fruhwunden - Astern sing interessant. Gartenwelt. No. 6. P. 127.

8. Kudryavets D.B., Sitov E.A. (1991). Chto vlijaet na kachestvo semjan. [What affects the quality of seeds]. Cvetovodstvo. No. 1. P. 12. [in Russian].

9. Kichunov N.I. (1976). Kitajskie astry. [Chinese asters]. Sad i ogorod. No. 8-9. P. 10-12. [in Russian].

10. Kotov V. (2010). Odnoletnjaja astra: cvetki i socvetija. [One-year-old astra: flowers and inflorescences]. Cvetovodstvo. No. 6. P. 22-23. [in Russian].

11. Iskrenko Z.I., Rudnik-Ivashhenko O.I., Shevel' L.A. (2015). Semennaja produktivnost' i uroven' dekorativnosti novyh sortov Callistephus chinensis (L.) Nees. [Seed productivity and decorative level of new varieties Callistephuschinensis (L.)]. Nees]. Electronic Scientific Journal "SCI-ARTICLE". No. 26. P. 87-93. [in Russian]. 